\title{
Analisis Anthropometri dan Physical Fitnes Dominan Penentu Kemampuan Shooting Sepakbola Pada Kawasan Daerah Pesisir Pantai Labuhan Badas Sumbawa
}

\author{
${ }^{\mathbf{1}}$ Sylvana Yaka Saputra, ${ }^{\mathbf{2} Z u l h a k i m}$ \\ ${ }^{1}$ Prodi Pendidikan Jasmani Kesehatan dan Rekreasi, Universitas Nahdlatul Ulama NTB \\ ${ }^{2}$ Prodi Ilmu Gizi, Universitas Nahdlatul Ulama NTB \\ Sylvanayakasaputra1990@gmail.com
}

\begin{abstract}
Abstrak. Dengan mempertimbangkan faktor anthropometri dan physical fitnes. Pelatih dapat mengukur dan mentakar metode latihan dengan mempertimbangkan kemampuan antropometri dan physical fitnes Dengan demikian para atlet berbakat dapat memaksimalkan kemampuanya dalam permainan sepakbola. Dan dapat dijadikan acuan dalam pencarian bibit olahraga sepakbola. Permasalah dalam penelitian ini adalah : diantara variabel Anthropometri (rasio panjang tungkai dan tinggi badan, berat badan), dan Physical Fitnes (power otot tungkai, kelentukan, dan keseimbangan) yang manakah lebih dominan mempengaruhi Shooting dalam sepakbola. Tujuan penelitian ini adalah untuk mengetahui variabel yang lebih dominan antara faktor anthropometri terdiri dari ( rasio panjang tungkai dan tinggi badan, dan berat badan) dan faktor Phisical Fitnes terdiri dari (power otot tungkai, fleksibilitas togok, dan keseimbangan) terhadap kemampuan shooting dalam permainan sepakbola. Berdasarkan nilai koefisien terstandar (standardized coefficient beta), variabel keseimbangan memiliki nilai yang paling tinggi yaitu sebesar 0,033 dibandingkan keempat variabel lainnya. Sehingga dinyatakan bahwa variabel keseimbangan merupakan variabel yang paling dominan dalam mempengaruhi kemampuan shooting dalam sepakbola, variabel power otot tungkai sebesar 0,109, Fleksibilitas Togok sebesar 0,059 sedangkan variabel yang tidak berpengaruh yaitu rasio tingi badan dan panjang tungkai (standardized coefficient beta ) 0,004, Berat badan 0,007
\end{abstract}

\section{Kata kunci: Antropometri, Physical Fitnes, Shooting, Sepakbola}

\section{PENDAHULUAN}

Olahraga mempunyai peranan yang penting dalam kehidupan manusia. Melalui olahraga dapat dibentuk manusia yang sehat jasmani, rohani serta mempunyai kepribadian, disiplin, sportivitas yang tinggi sehingga pada akhirnya akan terbentuk manusia yang berkualitas. Suatu kenyataan yang bisa diamati dalam dunia olahraga, menunjukkan kecenderungan adanya peningkatan prestasi olahraga yang pesat dari waktu kewaktu baik tingkat daerah, nasional maupun internasional. Hal ini dapat dilihat dari pemecahan pemecahan rekor yang terus dilakukan pada cabang olahraga tertentu, penampilan tehnik yang efektif dan efisien dengan ditinjau oleh kondisi fisik yang baik. Bentuk tubuh atau porsi tubuh yang ideal sesuai dengan cabang olahraga yang dipelajarinya merupakan salah satu syarat yang dapat mempengaruhi pencapaian prestasi olahraga. M. Sajoto (1995:11) menyatakan bahwa salah satu aspek dalam mencapai prestasi olahraga adalah aspek biologi yang meliputi struktur dan postur tubuh yaitu 1) ukuran tinggi dan panjang tungkai, 2) ukuran besar, lebar, dan berat badan, serta 3) somotype (bentuk tubuh). Tinggi badan yang ideal atau normal untuk ukuran merupakan salah satu syarat untuk mencapai prestasi dalam cabang olahragasepakbola khususnya kemampuan shooting. Perlu diketahui bahwa untuk badan yang ideal pada umumnya badan yang atletis dengan kecenderungan fisik yang baik.

Ukuran anthropometri mencangkup kuantitas dari dimensi-dimensi tubuh termasuk di dalamnya berat badan, ukuran panjang dan luas penampang tubuh atau bagian-bagian tubuh. Perbandingan dari masing-masing organ tubuh memberikan tampilan yang berbeda-beda pada masing-masing individu. 
Ukuran athropometri berkaitan dengan tipe atau bentuk tubuh, juga dapat dijadikan sebagai parameter untuk menentukan status gizi seseorang (Djoko Pekik Irianto, 2007: 67). Menurut pendapat dari kedua ahli bahwasannya faktor athrphometri dan faktor kondisi fisik sangat baik dimiliki oleh seorang atlet guna untuk mencapai puncak prestasi optimal. Dan menjadi landasan para pelatih untuk memilih atlet pada cabang olahraga tertentu dengan mempertimbangkan kedua faktor tersebut.

Permasalah dalam penelitian ini adalah diantara variabel Anthropometri (rasio panjang tungkai dan tinggi badan, berat badan), dan Physical Fitnes (power otot tungkai, kelentukan, dan keseimbangan) yang manakah lebih dominan mempengaruhi Shooting dalam sepakbola adapun Tujuan penelitian ini adalah untuk mengetahui variabel yang lebih dominan antara faktor anthropometri terdiri dari ( rasio panjang tungkai dan tinggi badan, dan berat badan) dan faktor Phisical Fitnes terdiri dari (power otot tungkai, fleksibilitas togok, dan keseimbangan) terhadap kemampuan shooting dalam permainan sepakbola.

\section{METODE PENELITIAN}

Pendekatan yang dilakukan dalam penelitian ini adalah pendekatan dengan menggunakan analisis regresi. Analisis regresi untuk mengukur besarnya pengaruh variabel bebas terhadap variabel tergantung dan memprediksi variabel tergantung dengan menggunakan variabel bebas. Gujarati (2006) mendefinisikan analisis regresi sebagai kajian terhadap hubungan satu variabel yang disebut sebagai variabel yang diterangkan (the explained variabel) dengan satu atau dua variabel yang menerangkan (the explanatory).

Teknik pengumpulan data penelitian ini dilakukan dengan prosedur yang diatur sebagai berikut: 1) menyiapkan alat yang akan digunakan, 2) menyiapkan sampel penelitian, 3) pengambilan data meliputi tes variabel bebas dan variabel terikat yang dilakukan dalam sehari. Data dari hasil tes digunakan dalam analisis data untuk pengujian hipotesis.
Adapun yang di ukur dalam penelitian ini adalah sebagai berikut: (1) Panjang tungkai, (2) tinggi badan, (3) Berat Badan, (4) Power Otot Tungkai, (5) Fleksibilitas Togok, (6) Keseimbangan (7) Shooting dalam Sepakbola.

Analisis data dalam Penelitian ini

1. Uji Persyaratan Analisis
a. Multikolinearitas
b. Heteroskedastisitas
c. Normalitas

2. Uji Hipotesis
a. Menghitung Persamaan Garis Regresi Linier Berganda
b. Uji t
c. Uji F
d. Koefisien Determinasi

\section{HASIL DAN PEMBAHASAN}

Deskripsi data Hasil Penelitian,

1. Deskripsi data Untuk variabel Rasio Panjang Tungkai dan Tinggi Badan (X1)

Distribusi Frekuensi Untuk Variabel Rasio Panjang Tungkai dan Tinggi Badan (X1)

Tertinggi $=64.70$

Terendah $=58,47$

Jarak Data $=$ Tertinggi - Terendah $=64.70$ $-58.47=6.23$

Banyaknya Kelas $=1+(3,3 * \log (\mathrm{n}))=$ $5,874 \rightarrow 6$

Panjang Kelas $=$ Jarak data $/ \mathrm{n}$ kelas $=1,09$ $\rightarrow 2$

\begin{tabular}{|c|c|}
\hline Kelas & $\mathrm{f}_{\text {abs }}$ \\
\hline $58,47-59,56$ & 5 \\
\hline $59,57-60,66$ & 8 \\
\hline $60,67-61,76$ & 6 \\
\hline $61,77-62,86$ & 9 \\
\hline $62.87-63.96$ & 0 \\
\hline $63.97-65.06$ & 1 \\
\hline Jumlah & 30 \\
\hline
\end{tabular}

Dapat dideskripsikan rasio panjang tungkai dan tinggi badan dibagi kedalam kelas interval 6 kelas interval panjang masing-masing kelas interval adalah 1.09 kelas interval pertama dimulai dari tinggi terendh responden yaitu 58,47 sampai 65,06 dengan panjang kelas $1.09 \mathrm{f}$ abs merupakan banyaknya frekuensi kelas interval.

2. Deskripsi data Untuk Variabel Berat Badan (X2) 
Distribusi Frekuensi Untuk Variabel Berat badan (X2)

$$
\begin{array}{ll}
\text { Tertinggi } & =70 \\
\text { Terendah } & =46 \\
\text { Jarak Data } & =\text { Tertinggi }- \text { Terendah } \\
=70-46=24 &
\end{array}
$$$$
\text { Banyaknya Kelas }=1+(3,3 * \log (\mathrm{n}))=
$$$$
5,874 \rightarrow 6
$$

Panjang Kelas = Jarak data $/ \mathrm{n}$ kelas $=$ $4 \rightarrow 4$

\begin{tabular}{|c|c|}
\hline Kelas & Fabs $_{\text {as }}$ \\
\hline $46-49$ & 1 \\
\hline $50-54$ & 7 \\
\hline $55-59$ & 8 \\
\hline $60-64$ & 9 \\
\hline $65-69$ & 3 \\
\hline $70-74$ & 2 \\
\hline
\end{tabular}

Dapat dideskripsikan berat badan dibagi kedalam kelas interval 6 kelas interval panjang masing-masing kelas interval adalah 6 kelas interval pertama dimulai dari terendah sampai tertinggi responden yaitu 46 sampai 74 dengan panjang kelas $4, \mathrm{f}$ abs merupakan banyaknya frekuensi kelas interval.

3. Deskripsi data Untuk Variabel Power Otot Tungkai (X3)

Distribusi Frekuensi Untuk Variabel

Power Otot Tunkai (X3)

Tertinggi $=73$

Terendah $=56$

Jarak Data $=$

Tertinggi - Terendah $=73-56=17$

Banyaknya Kelas

$=1+(3,3 * \log (n))=5,874 \rightarrow 6$

Panjang Kelas

Jarak data $/ \mathrm{n}$ kelas $=2.83 \rightarrow 3$

\begin{tabular}{|c|c|}
\hline Kelas & $\mathrm{F}_{\text {abs }}$ \\
\hline $56-59$ & 3 \\
\hline $60-63$ & 5 \\
\hline $64-67$ & 13 \\
\hline $68-71$ & 8 \\
\hline $72-75$ & 1 \\
\hline $76-79$ & 0 \\
\hline Jumlah & 30 \\
\hline
\end{tabular}

Dapat dideskripsikan power otot tungkai dibagi kedalam kelas interval 6 kelas interval panjang masingmasing kelas interval adalah 6 kelas interval pertama dimulai dari terendah sampai tertinggi, responden yaitu 56 sampai 79 dengan panjang kelas 4 , f abs merupakan banyaknya frekuensi kelas interval.

4. Deskripsi data Untuk Variabel

Keseimbangan (X4)

Tertinggi $=90.00$

Terendah $=10.50$

Jarak Data $=$ Tertinggi - Terendah $=$ $90.00-10.50=79.5$

Banyaknya Kelas $=1+(3,3 * \log (\mathrm{n}))=$ $5,874 \rightarrow 6$

Panjang Kelas $=$ Jarak data $/ \mathrm{n}$ kelas $=13.25$ $\rightarrow 13$

\begin{tabular}{|c|c|}
\hline Kelas & $F_{\text {abs }}$ \\
\hline $10.50-23.75$ & 5 \\
\hline $23.76-37.01$ & 2 \\
\hline $37.02-50.27$ & 6 \\
\hline $50.28-63.53$ & 9 \\
\hline $63.54-76.79$ & 5 \\
\hline $76.80-90.05$ & 3 \\
\hline Jumlah & 30 \\
\hline
\end{tabular}

Dapat dideskripsikan keseimbangan dibagi kedalam 6 kelas interval panjang masing-masing kelas interval adalah 6 kelas interval pertama dimulai dari terendah sampai tertinggi responden yaitu sebesar 10.50 sampai 90,05 dengan panjang kelas 13,25 f abs merupakan banyaknya frekuensi kelas interval.

5. Deskripsi data Untuk Variabel

Fleksibilitas Togok (X5)

Tertinggi $=30$

Terendah $=10$

Jarak Data $=$ Tertinggi - Terendah $=30-$ $10=20$

Banyaknya Kelas $=1+(3,3 * \log (\mathrm{n}))=$ $5,874 \rightarrow 6$

Panjang Kelas $=$ Jarak data $/ \mathrm{n}$ kelas $=$ $3.33 \rightarrow 3$

\begin{tabular}{|c|c|}
\hline Kelas & $\mathrm{F}_{\text {abs }}$ \\
\hline $10-13$ & 4 \\
\hline 14.17 & 5 \\
\hline $18-21$ & 4 \\
\hline $22-25$ & 5 \\
\hline $26-29$ & 10 \\
\hline $30-33$ & 2 \\
\hline Jumlah & 30 \\
\hline
\end{tabular}

Dapat dideskripsikan keseimbangan dibagi kedalam 6 kelas interval panjang 
masing-masing kelas interval adalah 6 kelas interval pertama dimulai dari terendah sampai tertinggi responden yaitu sebesar 10 sampai 33 dengan panjang kelas 3,33 dibulatkan ke bawah menjadi $3 \mathrm{f}$ abs merupakan banyaknya frekuensi kelas interval.

\section{Analisi Data}

\section{Uji Prasyarat Analisis}

Multikolinearitas

\begin{tabular}{|c|c|c|c|}
\hline \multirow{2}{*}{\multicolumn{2}{|c|}{ Model }} & \multicolumn{2}{|c|}{ CollinearityStatistics } \\
\hline & & Tolerance & VIF \\
\hline \multirow[t]{6}{*}{1} & (Constant) & & \\
\hline & $\mathrm{TB} / \mathrm{PT}$ & ,635 & 1,575 \\
\hline & $\mathrm{BB}$ & ,624 & 1,603 \\
\hline & POT & ,804 & 1,244 \\
\hline & KSB & ,824 & 1,214 \\
\hline & FLT & ,971 & 1,030 \\
\hline
\end{tabular}

Berdasarkan nilai VIF dan Tolerance, variabel tinggi badan terhadap panjang tungkai, berat badan, power otot tungkai, keseimbangan, serta variabel fleksibilitas togok tidak saling berkorelasi kuat satu sama lain. Dengan kata lain, model regresi yang dihasilkan tidak mengandung gejala multikolinearitas. Dimana nilai VIF semua variabel tersebut kurang dari 10 dan nilai Tolerance di atas 0,1 .

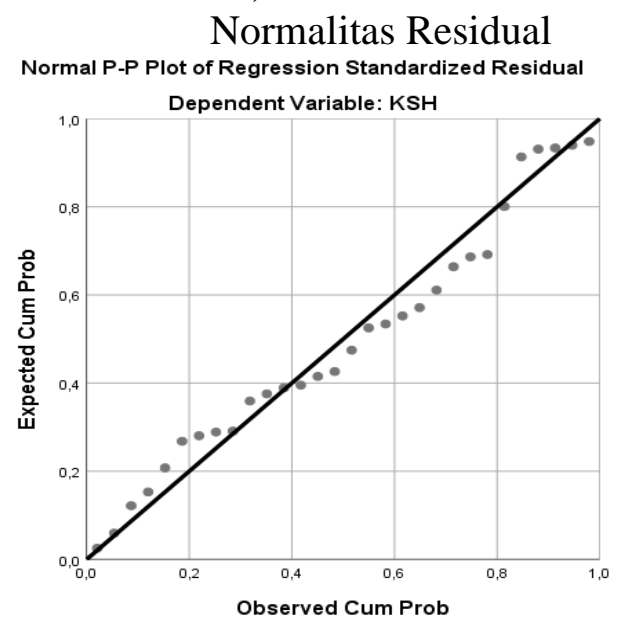

(Standardized residual) berada di sekitar garis diagonal. Karena itu, nilai residual dinyatakan terdistribusi normal atau memenuhi asumsi normalitas.Uji Hipotesis

Hasil Analisis Regresi Linear Berganda

\begin{tabular}{|c|c|c|c|c|c|c|}
\hline \multirow[b]{3}{*}{ Mode } & \multicolumn{6}{|c|}{ Coefficients $^{\mathrm{a}}$} \\
\hline & & \multicolumn{2}{|c|}{$\begin{array}{l}\text { Unstandardized } \\
\text { Coefficients }\end{array}$} & \multirow{2}{*}{$\begin{array}{c}\text { Standardized } \\
\text { Coefficients } \\
\text { Beta } \\
\end{array}$} & \multirow[b]{2}{*}{$\mathrm{T}$} & \multirow[b]{2}{*}{ Sig. } \\
\hline & & B & Std. Error & & & \\
\hline 1 & (Constant) & $-7,392$ & 10,456 & &,- 707 &, 486 \\
\hline & TB/PT & 004 & 140 & 004 & ,027 & 979 \\
\hline & BB & 007 & 030 & 035 & 239 & ,813 \\
\hline & POT & 109 & 037 & ,373 & 2,926 & 007 \\
\hline & KSB & 033 & 007 & ,587 & 4,655 & ,000 \\
\hline & FLT & ,059 & ,024 & 287 & 2,473 & ,021 \\
\hline
\end{tabular}

Berdasarkan nilai koefisien terstandar (standardized coefficient), variabel keseimbangan memiliki nilai yang paling tinggi dibandingkan keempat variabel lainnya. Sehingga dinyatakan bahwa variabel keseimbangan merupakan variabel yang paling dominan dalam mempengaruhi kemampuan shooting dalam sepakbola

\section{Hasil Uji Kelayakan Model Regresi} ANOVA ${ }^{\mathrm{a}}$

\begin{tabular}{|c|c|c|c|c|c|}
\hline Model & $\begin{array}{l}\text { Sum of } \\
\text { Squares }\end{array}$ & $\mathrm{df}$ & $\begin{array}{l}\text { Mean } \\
\text { Square }\end{array}$ & $\mathrm{F}$ & Sig. \\
\hline $1 \quad$ Regression & 32,103 & 5 & 6,421 & 10,484 &, $000^{b}$ \\
\hline Residual & 14,697 & 24 & 612 & & \\
\hline Total & 46,800 & 29 & & & \\
\hline
\end{tabular}

Hasil uji $F$ menunjukkan nilai $F$ hitung sebesar 10,484 dengan nilai $p$ (sig.) $0,000<0,05$, sehingga model regresi dinyatakan layak. Hal ini berarti bahwa secara simultan variabel rasio tinggi badan terhadap panjang tungkai, berat badan, power otot tungkai, keseimbangan, dan variabel fleksibilitas togok berpengaruh signifikan terhadap kemampuan shooting dalam sepakbola

Hasil Uji Hipotesis

\begin{tabular}{|c|l|r|r|l|l|}
\hline Hipotesis & \multicolumn{1}{|c|}{ Pengaruh } & t-hitung & Sig. & Keputusan & Keterangan \\
\hline H1 & $\begin{array}{l}\text { TB/PT } \rightarrow \\
\text { KSH }\end{array}$ & 0,027 & 0,979 & Tolak H1 & Non Signifikan \\
\hline H2 & BB $\rightarrow$ KSH & 0,239 & 0,813 & Tolak H2 & Non Signifikan \\
\hline H3 & POT $\rightarrow$ KSH & 2,926 & 0,007 & Terima H3 & Signifikan \\
\hline H4 & KSB $\rightarrow$ KSH & 4,655 & 0,000 & Terima H4 & Signifikan \\
\hline H5 & FLT $\rightarrow$ KSH & 2,473 & 0,021 & Terima H5 & Signifikan \\
\hline
\end{tabular}

1. Pengujian untuk Variabel Rasio Panjang Tungkai dan Tinggi Badan (X1)

Untuk H1 (hipotesis pertama) diperoleh nilai t-hitung $(0,027)<$ t-tabel $(2,060)$ atau nilai sig. $(0,979)>0,05$, sehingga keputusan yang diambil adalah menolak H1. Hal ini berarti bahwa rasio tinggi badan terhadap panjang tungkai tidak berpengaruh 
signifikan terhadap kemampuan shooting dalam sepakbola.

\section{Pengujian untuk Variabel Berat Badan (X2)}

Untuk $\mathrm{H} 2$ (hipotesis kedua) diperoleh nilai t-hitung $(0,239)<$ t-tabel $(2,060)$ atau nilai sig. $(0,813)>0,05$, sehingga keputusan yang diambil adalah menolak $\mathrm{H} 2$. Hal ini berarti bahwa berat badan tidak berpengaruh signifikan terhadap kemampuan shooting dalam sepakbola

\section{Pengujuian Untuk Variabel Power Otot Tungkai (X3) \\ Untuk H3 (hipotesis ketiga) diperoleh} nilai t-hitung $(2,926)>$ t-tabel $(2,060)$ atau nilai sig. $(0,007)<0,05$, sehingga keputusan yang diambil adalah menerima H3. Hal ini berarti bahwa power otot tungkai berpengaruh signifikan terhadap kemampuan shooting dalam sepakbola

\section{Pengujian Untuk Variabel Keseimbangan (X4)}

Untuk H4 (hipotesis keempat) diperoleh nilai t-hitung $(4,655)>t$-tabel $(2,060)$ atau nilai sig. $(0,000)<0,05$, sehingga keputusan yang diambil adalah menerima H4. Hal ini berarti bahwa keseimbangan berpengaruh signifikan terhadap kemampuan shooting dalam sepakbola

5. Pengujian Untuk Variabel Fleksibilitas Togok (X5)

Untuk H5 (hipotesis kelima) diperoleh nilai t-hitung $(2,473)>t$-tabel $(2,060)$ atau nilai sig. $(0,021)<0,05$, sehingga keputusan yang diambil adalah menerima H5. Hal ini berarti bahwa fleksibilitas berpengaruh signifikan terhadap kemampuan shooting dalam sepakbola

\section{KESIMPULAN}

Berdasarkan Hasil Penelitian Antropometri dan Physical Fitnes Rasio Tinggi badan dan panjang tungkai, Berat badan, Power otot tngkai, Keseimbangan dan Fleksibilitas togok.

Berdasarkan nilai koefisien terstandar (standardized coefficient beta), variabel keseimbangan memiliki nilai yang paling tinggi yaitu sebesar 0,033 dibandingkan keempat variabel lainnya. Sehingga dinyatakan bahwa variabel keseimbangan merupakan variabel yang paling dominan dalam mempengaruhi kemampuan shooting dalam sepakbola, variabel power otot tungkai sebesar 0,109, Fleksibilitas Togok sebesar 0,059 sedangkan variabel yang tidak berpengaruh yaitu rasio tingi badan dan panjang tungkai (standardized coefficient beta) 0,004, Berat badan 0,007

\section{DAFTAR PUSTAKA}

Djoko Pekik Irianto. 2007. Panduan Gizi Lengkap Keluarga dan Olahragawan. Yogyakarta: C.V ANDI OFFSET.

Gujarati, Damodar. (2006). Dasar-Dasar Ekonometrika. Jakarta : Erlangga

Ismaryanti. (2008). Tes dan Pengukuran Olahraga. Surakarta: UNS Press.

Priyatno, Duwi. (2012). Cara Kilat Belajar Analisis Data dengan SPSS 20. Edisi kesatu. Yogyakarta : ANDI dst.

Sajoto M. (1995). Pembinaan Kekuatan Kondisi Fisik Dalam Olahraga. Semarang: Effhar \& Dahara Prize Offset. 